releasing ketones of Tapinoma, Liometopym and Monacis act intergenerically.

In some genera species-specificity was examined. In Myrmica it has been shown that the venom of $M$. laevin. odis, sulcinodis and rubida stimulates alarm in $M$. ruginodis, and vice versa. The mandibular gland substances, too, are not species-specific in ruginodis, sulcinodis and laevinodis. Mandible gland substance from $M$. rubinda, however, is not so effective as the secretions of the other species, although its gland is much bigger than that of M. ruginodis. This is understood because it belongs to a different sub-species (Neomyrma) from the three others. For the human nose its odour is also different from that of the three others. The mandibular gland substances and the Dufour gland substances of the three species of Formica (polyctena, cinerea, fusca) are reciprocally effective, likewise the Dufour gland substances of four species of Lasius (niger, fuliginosus, brunneus and flavus). For the human nose the Dufour gland substances of Lasius, F'ormica and Plagiolepis have the same odour, therefore their intergenerical effectiveness was investigated. The results were positive (Fig. 4).

For Myrmica ruginodis, however, with the exception of the abdominal substance of Pheidole pallidula, the alarm substances of other myrmicines, such as Messor, Tetra. morium, Leptothorax, are ineffective.

In summary, it may be said that the alarm substances of the social Hymenoptera are always connected with organs and glands of defence (with the mandibles, the sting, or anal glands). They originate either separated from the vonom and are mixed with it when released (honey-bee and Camponotinae) or they originate directly from the venom gland. In the latter case they can be identical with the venom (formic acid in Formica, ketones in Dolichoderinae) or not (Vespa, Myrmicinae). The specifically acting substances are released when the workers are excited. The alarmed insects usually attack but sometimes they fly away. The alarm substances are not species-specific as a rule; in Camponotinae, even. intergenerically acting substances were found.
So far only highly organized Hymenoptera colonies with great numbers of workers have been treated. They all possess alarm substances. Some Hymenoptera colonies, however, have been found which cannot give a chemical alarm. In bees three species of bumble bees were found (Bombus lucorum, hortorum and hypnorum), in wasps Polistes dubia, and in ants Ponera coarctata (Ponerinae) and Myrmecina graminicola (Myrmicinae). All these colonies are vory small and have only a few workers, usually less than 100. A disturbance can be directly noted by all nest inhabitants. Therefore development of a chemical alarm system seems to be biologically unnecessary for them.

I thank Springer-Verlag (Heidelberg) for permission to reproduce the illustrations, which appeared first in Zeitschrift für vergleichende Physiologie, 47, 596 (1964).

\footnotetext{
${ }^{1}$ Huber, F., Nouvelles observations sur les abeilles (Paris, 1814).

${ }^{2}$ Staeger, R., Z. wiss. Insektenbiol., 26, 125 (1931).

${ }^{3}$ Weyrauch, W., Biol. Zbl., 55, 484 (1935).

4 Goetsch, W., Z. Morph. Okol. Tiere, 28, 319 (1934).

${ }^{6}$ Free, J., Anim. Behav., 9, 193 (1961).

${ }^{6}$ Lecomte, J., Ann. Abeille, 4, 165 (1961).

'Ghent, R. L., and Gary, L. E., Pryche, 69, 1 (1962).

${ }^{8}$ Boch, R., Shearer, D. A., and Stone, B. C., Nature, 195, 1018 (196.).

${ }^{9}$ Wilson, E. O., Psyche, 65, 41 (1958).

${ }^{10}$ Wilson, E. O., and Pavan, M., Psyche, 66, 70 (1959).

${ }^{11}$ Sudd, J. H., Nature, 178, 431 (1957).

12 Brown, L. W., Psyche, 66, 25 (1960).

${ }^{13}$ Hunt, T. J., Nature, 179, 875 (1957).

14 Butenandt, A., Linzen, B., and Iindauer, M., Arch. Anat. micr. Morph. exp., 48, 13 (1959).

tö Trave, R., and Pavan, M., Chim. e Indust., 38, 1015.

${ }^{16}$ Blum, M. S., Warter, S. L., Monroe, R. S., and Chidester, J. C., J. Inst. Physiol., 9, 881 (1963).

17 Maschwitz, U. W., Z. vergl. Physiol., 47, 596 (1964).

${ }^{18}$ Snodgrass, R. E., Anatomy of the Honeybee (New York, 1956).

19 Boch, R. (personal communication).

${ }^{20}$ Pavan, M., Proc. Fourth Internat. Congr. Biochem., Wien, 15 (1958).

${ }^{21}$ Carthy, J. D., Behaviour, 3, 304 (1951).

${ }^{22}$ Wilson, E. O., Science, 129, 643 (1959).

${ }^{23}$ Stumper, R., Mitt. schweiz. entomol. Ges., 29, 373 (1956).

is Wilson, E. O., Anim. Behav., 10, 134 (1962).

ns Wilson, E. O., Durlach, X., and Roth, L., Psyche, 65, 108 (1958),
}

\title{
OBITUARIES
}

\section{Dr. L. E. Bayliss}

LEONARD BAyuIss, who died on August 20 in his sixty-fourth year, was widely known for three achievements: his work on the rheology of blood, his notable two-volume Principles of General Physiology in 1959 and 1960 and, particularly to medical students, as co-author of Human Physiology in five editions (1930-62).

Blood rheology investigations began about 1930 after he had spent a year in Philadelphia with A.. N. Richards collecting glomerular fluid from frogs' kidneys with micropipettes and comparing its oncotic pressure with that of the plasma. Earlier, he had worked with his uncle, E. H. Starling, professor of physiology in University College London, on heart-lung-kidney preparations of dogs, investigating oxygenation and $\mathrm{pH}$ of the blood and metabolism of the preparation. A.bout then, Fåhraeus discovered the decrease in the apparent viscosity of blood in small tubes, but failed to induce blood to flow through tubes as small as arterioles because they became blocked with agglutinated red corpuscles. Bayliss, with micropipette technique and with defibrinated blood from heart lung preparations which agglutinates less, was able to measure the apparent viscosity in blood flowing in $20 \mu$ glass tubes, that is, arteriole size, and found it about onehalf that when the same blood passed through tubes of $500 \mu$ diameter or more. The paper describing this was refused for publication, presumably because the conclusion was so unlikely or perhaps because physiologists would not understand it. It remained in his drawer for a decade or more. Bayliss was always reluctant to publish. The conclusion leaked out as a 'personal communication' in a paper on the apparent viscosity of blood in hind limbs (1933) in which arterioles are about the same size, $20 \mu$, and form the main resistance to the flow of blood. Happily, the apparent viscosity in hind limbs was the same as that in Bayliss's small glass tubes.

The anomalous viscosity of blood was attributed by Fahraeus to axial concentration of the cells which slipped, as an almost solid rod, through nearly cell-free serum which separated the rod from the glass of the tube. Bayliss's later investigations attempted to test this hypothesis by comparing the viscosity obtained by direct measurement with that calculated from the distribution of optical density of different layers of blood flowing in microtubes when distortion due to refraction has been overcome or mathematically allowed for. His latest. review on the rheology of blood is in the great American. Handbook of Physiology, Section 2 on "Circulation" (1; 1962).

Fifty years ago, physiology had established itself as an independent science, pursued for the most part by medically qualified physiologists in the hope of increasing our understanding of normal, and to some extent disease, processes in man. Hence, many of the text-books included 'Human Physiology' in their titles, though they described, almost exclusively, experiments on animals other than man. Into this setting, Sir William, father of Leonard 
Bayliss, launched his Principles of General Physiology, which aimed at application of physical and physicochemical principles, rather outside the knowledge or interests of most medically qualified physiologists at that time, to the functions of cells, tissues and animals. Moreover, he ranged widely over the animal kingdom beyond the frog, cat and dog, which were the conventional objects of physiological investigation. This stirred almost ex. plosive interest among physiologists, many of whom, from home and abroad, were welcome guests at Sir William and Lady Bayliss's hospitable house in Hampstead. Into this setting, Leonard grew up to hear much discussion and to gain practical experience in his father's private laboratory and workshop, in addition to formal education at University College School and later in Trinity College, from which he took his degree in physiology at Cambridge and then his $\mathrm{Ph} . \mathrm{D}$.

After a year as physiologist at the Marine Biological Laboratory at Plymouth, he became lecturer in physiology in the University of Edinburgh. By 1939, however, physical chemistry, physiology and experimental zoology had advanced mightily in the twenty-five years since the original publication of the Principles, and Bayliss resigned from his salaried post to devote himself to study so as to produce a new synthesis of the cognate parts of these subjects; this he did at his father's professional home, University College, London. The War intervened, and during these years he must have been immensely active in the Army Operational Research Group, about which he spoke with real enthusiasm (see following note).

With the shortage of university staff after the War, he hecame reader in physiology at University College and managed, practically single-handed, in 1946 to restart the Hons. B.Sc. course which had perforce lapsed during the war years. Having set that on its feet, he resigned in 1950 in order to have leisure to pursue his ambition to create a new synthesis in the form of the Principles of Ceneral Physiology. This he achieved in two volumes published in 1959 and 1960, although he had continued teaching and research in an honorary capacity much as before.

He and his wife, Dr. M. Grace Eggleton, who survives him, were a devoted couple, both working in the same department and nearly always together, either in London or at their cottage in Sussex. He was a modest, frugal and exceedingly kind person, always ready to interrupt what he was doing to discuss someone else's problem; unambitious and reluctant to publish papers, though he published quite a few about widely diverse branches of physiology from water-diuresis to action-potentials. A glimpse of his generous character appears in a quotation from his preface to the Principles of General Physiology, 1, in the acknowledgments: "But the most valuable of all my assistance has come, whether they knew it or not, from my colleagues and students in the course of discussion and instruction".

F. R. WINTON

ONE morning in the autumn of $1940 \mathrm{I}$ was gazing ruefully at the smoking ruins at University College, when Leonard Bayliss came and stood beside me. I had been looking for scientific people for Blackett's party at AntiAircraft Command and said, "Leonard, do you want a job ?" The job seemed particularly pertinent then, and he said "Ycs" at once. For nearly five years he worked with the Army Operational Research Group under its various titles, and was a leading member of its establish. ment throughout the War, contributing greatly to its success.

The efforts of this Group were of tremendous value to the A.A. Command. As General Pile wrote in his despatch (London Gazette, December I6, 1947), "While full credit must be given to the troops of all kinds, and indeed their conduct . . . was beyond all praise, the foundation of success was laid by the scientist, both civilian and in uniform". In his book $A c k-A c k$ is a photograph of Pile talking to Bayliss, with other members of the team around.

The original party was split early into two sections: (a) those engaged in radar problems; (b) those dealing more generally with fire control and analysis. Bayliss was put in charge of the latter. A colleague of those days writes that he was "always delightfully helpful and stimulating"; and he was himself the author of many reports on A.A. gunnery, A.A. predictors, accuracy of fire against aircraft at various heights, and later against flying bombs. These were enlivened occasionally by touches of the gentle irony that his friends will recall.

It may seem remarkable that one who had no previous experience of war and its problems should have been able, immediately, to take so active and successful a part. But this does not seem so remarkable to those who knew Bayliss's breadth of knowledge and ingenuity, and his engaging readiness to help.

A. V. Hill

\section{Dr. Arvid Hjalmar Uggla}

By the recent death of Dr. Arvid Uggla in his eightysecond year, the learned world has lost a great authority on everything connected with Linnæus. When Dr. J. M. Hulth of the University Library, Uppsala, published his excellent Bibliographia Linnaeana in 1907, ho stated his intention of undertaking a work on Linnæus's manuscripts, but his promotion to the head librarianship of the University Library, Uppsala, and his oariy death prevented him from carrying out this project. After his service in the Swedish Army during the First World War, Arvid Uggla returned to the University Library. Uppsala, becoming one of its principal librarians. Frorn about the year 1928, when Uggla published his first paperon Linnæus, he began a series of visits to England with the purpose of a close study of the Linnæan manuscripts. His profound study of these numerous manuscripts solved some problems long overdue. Some of these solutions were published in the year-book (Arsskrift) of the Swedish Linnean Society (Svenska Linné-Sällskapet) but many remain unpublished. Unlike previous research workers, he also thoroughly investigated the many manuscripts of the younger Linnæus, and was able to show that, although lacking the elder Linnæus's genius, that somewhat denigrated young man was quite a considerable naturalist. Although he prepared a valuable hand-list in manuscript and deposited a copy at the Linnean Society of London, his projected eatalogue of the Linnæan manuscripts remains unpublished. It is hoped that Svenska Linné-Sällskapet will publish this catalogue as its tribute to his memory.

Only those who have made some study of the Linnæa? manuscripts can form any idea of the difficulties connected with them. Apart from the fact that many of the manuscripts still consist of loose leaves (at times in doubtful order) there are the ever-present difficulties connected with reading the sometimes almost illegible handwritings. Uggla had the quick mind and keen oye necessary to do such work to perfection. In addition, he had wonderful powers of memory, which enabled him to associate immediately with other manuscripts the one he was investigating.

Apart from the xumerous papers published in the Arsskrift and elsewhere, Uggla published several separate works. Among them, with E. Malmeström (now Bishop of Uppsala), he collaborated in a revised edition of Linnæus's soveral autobiographies in Vita Caroli Linnaei (1957).

Svenska Linné-Sállskapot devoted its Arsskrift for 1962 , published in 1963, as a festschrift to Dr. Uggla on his eightieth birthday, February 13, 1963. In it will bo found the reproduction of an excellent bas-relief portrait of Dr. Uggla, and a bibliography of his writings. From 1927 he was secretary of the Swedish Linnean Socioty and editor of its Arsskrift, as well as superintendent of the Linné Museum, Uppsala. 